\title{
Polyphenolic Composition, Antioxidant and Antibacterial Activities for Two Romanian Subspecies of Achillea distans Waldst. et Kit. ex Willd.
}

\section{Daniela Benedec ${ }^{1}$, Laurian Vlase ${ }^{2}$, Ilioara Oniga ${ }^{1}$, Augustin C. Mot ${ }^{3}$, Grigore Damian ${ }^{4}$, Daniela Hanganu $^{1, *}$, Mihaela Duma ${ }^{5}$ and Radu Silaghi-Dumitrescu ${ }^{3}$}

1 Department of Pharmacognosy "Iuliu Hatieganu" University of Medicine and Pharmacy, 12 I. Creanga Street, Cluj-Napoca 400010, Romania; E-Mails: dbenedec@umfcluj.ro (D.B.); ioniga@umfcluj.ro (I.O.)

2 Department of Pharmaceutical Technology and Biopharmaceutics, 12 I. Creanga Street, Cluj-Napoca 400010, Romania; E-Mail: laurian.vlase@umfcluj.ro

3 Department of Chemistry and Chemical Engineering "Babes-Bolyai"University, 11 A. Janos Street, Cluj-Napoca 400028, Romania; E-Mails: augustinmot@chem.ubbcluj.ro (A.C.M.); rsilaghi@chem.ubbcluj.ro (R.S.-D.)

4 Department of Physics, ’Babes-Bolyai’University, 11 A. Janos Street, Cluj-Napoca 400028, Romania; E-Mail: grigore.damian@phys.ubbcluj.ro

5 State Veterinary Laboratory for Animal Health and Safety, 1 Piata Marasti Street, Cluj-Napoca 400609, Romania; E-Mail: duma.alexandru-cj@ansvsa.ro

* Author to whom correspondence should be addressed; E-Mail: dhanganu@umfcluj.ro; Tel./Fax: +40-74200-9682.

Received: 1 July 2013; in revised form: 18 July 2013 / Accepted: 18 July 2013 /

Published: 24 July 2013

\begin{abstract}
The aim of this work was to study the chemical composition, antioxidant and antibacterial properties of Achillea distans Waldst. et Kit. subsp. distans and Achillea distans Waldst. et Kit. subsp. alpina Rochel, from the Rodna Mountains (Romania). The identification and quantification of major phenolic compounds was performed by a HPLC-MS method. The total polyphenolic and flavonoid content was determined spectrophotometrically. The antioxidant activity was evaluated using the DPPH bleaching method, trolox equivalent antioxidant capacity assay (TEAC), hemoglobin ascorbate peroxidase activity inhibition (HAPX) assay, and an Electron Paramagnetic Resonance (EPR) spectroscopy method. A data indicated that A. distans subsp. alpina extract has more antioxidant activity than $A$. distans subsp. distans extract. Luteolin, apigenin,
\end{abstract}


quercetin, caffeic and chlorogenic acids were present in the two extracts of $A$. distans, but in different amounts. Three flavonoids were detected only in A. distans subsp. alpina. The polyphenol-richer $A$. distans subsp. alpina extract showed a higher antioxidant activity than A. distans subsp. distans extract. A. distans subsp. distans extract showed inhibitory activity for Gram-positive bacteria, as evaluated with four species. The quantitative and qualitative differences between the two subspecies of Achillea distans could be used as a potential taxonomic marker in order to distinguish the species.

Keywords: Achillea distans; polyphenols; antioxidant activity; hemoglobin; EPR

\section{Introduction}

The genus Achillea (Asteraceae) is represented by about 85 species throughout the World, and 23 species and 10 varieties or subspecies can be found in the Romanian flora. Some Achillea species have ethnopharmacologic importance and are known to be used in folk remedies for various purposes [1,2]. Achillea distans Waldst. et Kit. ex Willd. (Alps yarrow) is an Alpino-Carpatho-Balkan species that vegetates on the upper limit of mountain forests and in subalpine shrubs. According to the length of ligulate florets and to their color, two subspecies are recognized: Achillea distans Waldst. et Kit. subsp. Distans, with white flowers and about $2 \mathrm{~mm}$ length of ligulae and Achillea distans Waldst. et Kit. subsp. alpina (Rochel) Soó, with pink flowers and about $3 \mathrm{~mm}$ length of ligulae [1-3]. Due to the differences in the chemical composition of the essential oils of $A$. distans subsp. distans and A.distans subsp. alpine, these were considered as infraspecific chemical taxa or chemovarieties of Achillea distans [3]. Achillea distans Waldst. et Kit. ex Willd., found in the Rodna Mountains (a subdivision of the Eastern Carpathians in Northern Romania), was confirmed as a native species of the Romanian flora [1]. The flower heads of $A$. distans species contain essential oils, polyphenolic compounds, terpenoids; the essential oil and the tincture showed antimicrobial and anti-inflammatory activities [4-7]. The roots of A. distans subsp. distans also contain essential oil [8].

Phenolic compounds are a major group of compounds acting as primary antioxidants or free radical scavengers; flavonoids are a ubiquitous group of the polyphenolic substances which are present in all higher plants [9]. The total phenolic compounds and flavonoid content are also related to the antioxidant activity. Over the past decade, major advances have been made to investigate the antioxidant and antimicrobial properties of different Achillea species: A. alexandri-regis Bornm. \& Rudsky [10], A. biebersteinii Afan. [11], A. moschata Wulf., A. distans Waldst. \& Kit. ex Willed. [12], A. micrantha Willd., A. filipendula Lam., A. tenuifolia Lam., A. vermicularis Trin., and A. wilhelmsii C. Koch. [13], A. santolina [14], A. ptarmica L., A. nobilis L. [15], A. millefolium L. [13,16-19], A. ligusta All. [20], A. collina Becker, A. pannonica Scheele [21,22], A. teretifolia Waldst. and Kitt, A. schischkinii Sosn. [23]. Only one of the studies evaluated the antioxidant activity of Achillea distans from northern Italy, showing that methanolic extracts from the flowering parts possess antioxidant activity, by employing DPPH and LDL oxidation assays [12]. Scientific data on the two subspecies (alpina and distans) of $A$. distans are very limited. 
The aim of the present paper was to characterize the polyphenolic composition of hydroalcoholic extracts from the flowers of two subspecies of Achillea distans Waldst. et Kit. ex Willd.: Achillea distans Waldst. et Kit. subsp. distans and Achillea distans Waldst. et Kit. subsp. alpina (Rochel) Soó, and to evaluate their in vitro antioxidant and antibacterial activities.

\section{Results and Discussion}

\subsection{HPLC Analysis of Polyphenols}

HPLC coupled with MS is a very powerful analytical technique, due to its high sensitivity and the structural information that can be obtained about the analytes. A high-performance liquid chromatographic (HPLC) method has been developed for the determination of 19 phenolic compounds (eight phenolic acids, four quercetin glycosides, and seven flavonol and flavone aglycones) from plant material. The applicability of the proposed analytical method and the qualitative and quantitative determination of the standard phenolic compounds have already been verified [4,24-26]. The method allows a simultaneous analysis of different classes of polyphenols by a single pass column (the separation of all examined compounds was carried out in $35 \mathrm{~min}$ ). The concentrations of identified polyphenolic compounds in both analyzed samples are presented in Table 1. They were shown in the order of their retention time. The HPLC chromatogram of $A$. distans subsp. distans sample is presented in Figure 1 and the HPLC chromatogram of $A$. distans subsp. alpina sample is presented in Figure 2. The quantitative determination was performed using the external standard method (Table 2).

In the ethanolic extract of $A$. distans subsp. distans flowers, luteolin was the compound found in the largest amount $(763.12 \pm 1.88 \mathrm{mg} / 100 \mathrm{~g})$ followed by apigenin $(264.84 \pm 1.16 \mathrm{mg} / 100 \mathrm{~g})$. We detected quercetin at lower levels than major flavonoides $(1.44 \pm 0.06 \mathrm{mg} / 100 \mathrm{~g})$. Caffeic acid and chlorogenic acid were also identified in this extract, but they were in too low concentration to be quantified (Table 1).

Table 1. Polyphenolic compounds content in Achillea distans subspecies (mg/100 g plant material).

\begin{tabular}{ccccc}
\hline $\begin{array}{c}\text { Polyphenolic } \\
\text { compounds }\end{array}$ & $\begin{array}{c}\boldsymbol{m} / \boldsymbol{z} \\
\text { value }\end{array}$ & $\begin{array}{c}\mathbf{t}_{\mathbf{R}} \pm \mathbf{S D} \\
(\mathbf{m i n})\end{array}$ & $\begin{array}{c}\text { Achillea distans } \\
\text { subsp. distans }\end{array}$ & $\begin{array}{c}\text { Achillea distans } \\
\text { subsp. alpina }\end{array}$ \\
\hline Caffeic acid & 179 & $5.60 \pm 0.04$ & $<0.2$ & $<0.2$ \\
Chlorogenic acid & 353 & $5.62 \pm 0.05$ & $<0.2$ & $<0.2$ \\
Hyperoside & 463 & $18.60 \pm 0.12$ & $\mathrm{NF}$ & $2.05 \pm 0.10$ \\
Isoquercitrin & 463 & $19.60 \pm 0.10$ & $\mathrm{NF}$ & $<0.2$ \\
Rutin & 609 & $20.20 \pm 0.15$ & $\mathrm{NF}$ & $<0.2$ \\
Quercetin & 301 & $26.80 \pm 0.15$ & $1.44 \pm 0.06$ & $1.11 \pm 0.09$ \\
Luteolin & 285 & $29.10 \pm 0.19$ & $763.12 \pm 1.88$ & $52.65 \pm 0.85$ \\
Apigenin & 279 & $33.10 \pm 0.15$ & $264.84 \pm 1.16$ & $13.47 \pm 0.53$ \\
\hline
\end{tabular}

Note: NF - not found, below limit of detection. Values are the mean $\pm \operatorname{SD}(n=3)$. 
Figure 1. HPLC chromatogram of $A$. distans subsp. distans.

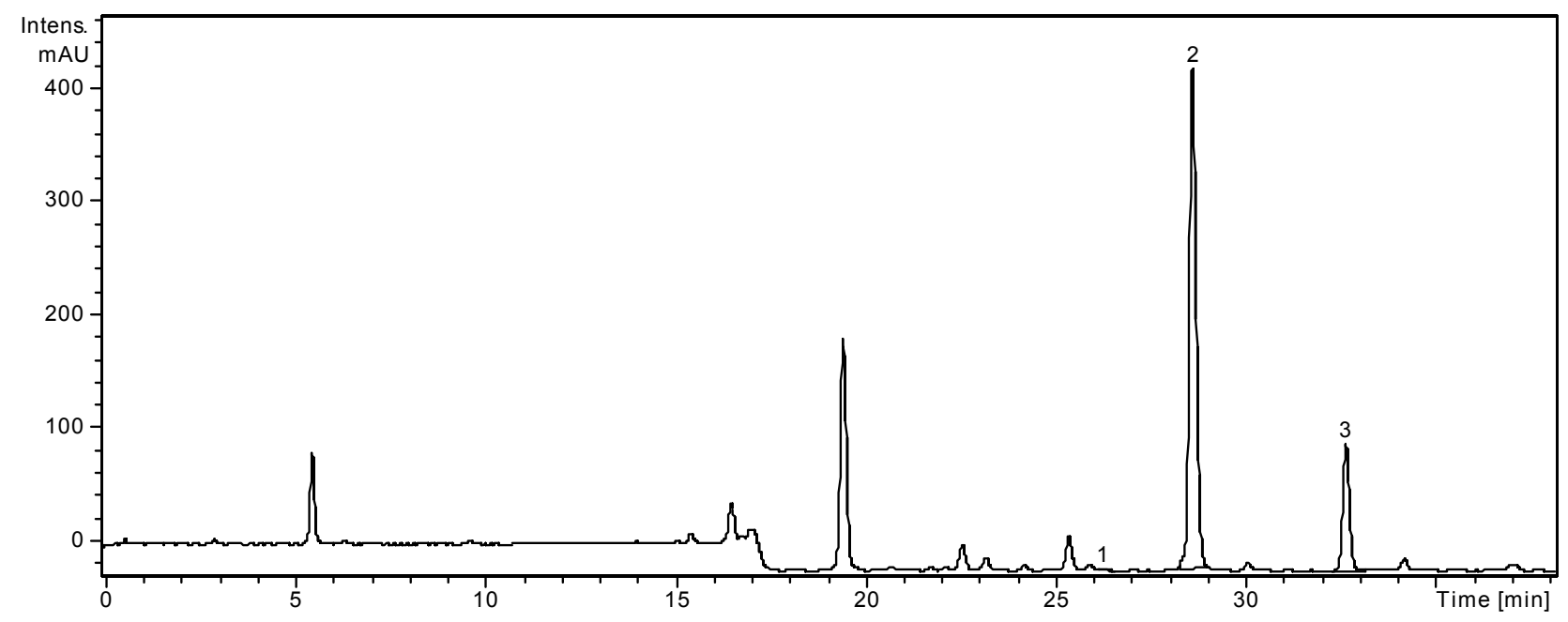

Notes: Chromatographic conditions were as given in the Experimental section. The identified compounds: 1, Quercetin; 2, Luteolin 3, Apigenin.

Figure 2. HPLC chromatogram of $A$. distans subsp. alpina.

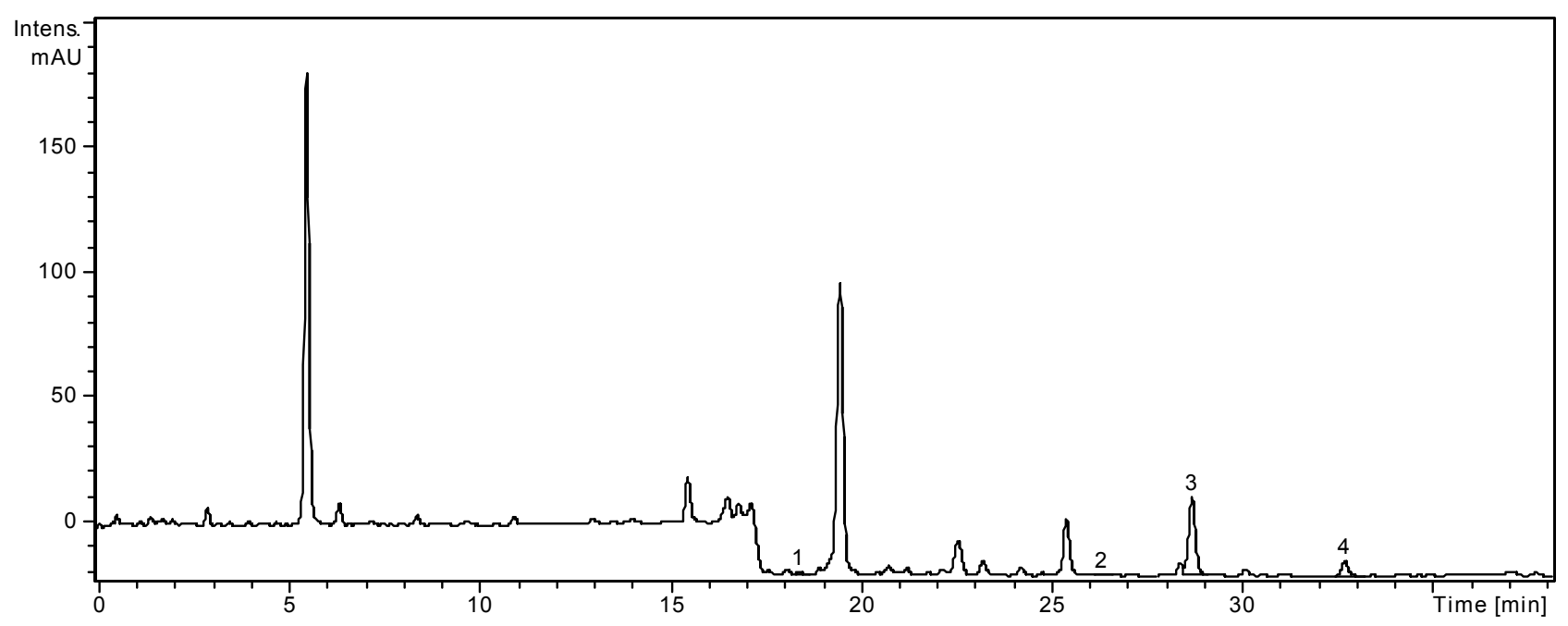

Notes: Chromatographic conditions were as given in the Experimental section. The identified compounds: 1, Hyperoside; 2, Quercetin; 3, Luteolin; 4, Apigenin.

Table 2. Retention times (RT) of polyphenolic compounds (min).

\begin{tabular}{cccc}
\hline Peak no. & Phenolic compounds & $\boldsymbol{m} / \boldsymbol{z}$ & $\mathbf{t}_{\mathbf{R}} \pm \mathbf{S D}(\mathbf{m i n})$ \\
\hline 1. & Caftaric acid & 311 & $3.54 \pm 0.05$ \\
2. & Gentisic acid & 179 & $6.52 \pm 0.04$ \\
3. & Caffeic acid & 179 & $5.60 \pm 0.04$ \\
4. & Chlorogenic acid & 353 & $5.62 \pm 0.05$ \\
5. & $p$-Coumaric acid & 163 & $9.48 \pm 0.08$ \\
6. & Ferulic acid & 193 & $12.8 \pm 0.10$ \\
7. & Sinapic acid & 223 & $15.00 \pm 0.10$ \\
8. & Cichoric acid & 473 & $15.96 \pm 0.13$ \\
9. & Hyperoside & 463 & $18.60 \pm 0.12$ \\
10. & Isoquercitrin & 463 & $19.60 \pm 0.10$ \\
\hline
\end{tabular}


Table 2. Cont.

\begin{tabular}{cccc}
\hline Peak no. & Phenolic compounds & $\boldsymbol{m} / \boldsymbol{z}$ & $\mathbf{t}_{\mathbf{R}} \pm \mathbf{S D}(\mathbf{m i n})$ \\
\hline 11. & Rutin & 609 & $20.20 \pm 0.15$ \\
12. & Myricetin & 317 & $21.13 \pm 0.12$ \\
13. & Fisetin & 285 & $22.91 \pm 0.15$ \\
14. & Quercitrin & 447 & $23.64 \pm 0.13$ \\
15. & Quercetin & 301 & $26.80 \pm 0.15$ \\
16. & Patuletin & 331 & $29.41 \pm 0.12$ \\
17. & Luteolin & 285 & $29.10 \pm 0.19$ \\
18. & Kaempferol & 285 & $32.48 \pm 0.17$ \\
19. & Apigenin & 279 & $33.10 \pm 0.15$ \\
\hline
\end{tabular}

Note: SD, standard deviation.

In the extract of $A$. distans subsp. alpina flowers, the two free aglycones, i.e., apigenin and luteolin, were found in much smaller amounts than in "distans" subspecies $(13.47 \pm 0.27$, and $52.65 \pm 0.85 \mathrm{mg} / 100 \mathrm{~g}$, respectively). Quercetin was detected in small amounts $(1.11 \pm 0.09 \mathrm{mg} / 100 \mathrm{~g})$. In this extract, three flavonoid glycosides were identified. Hyperoside (quercetin 3-O-galactoside) was determined in quantities of $2.05 \pm 0.10 \mathrm{mg} / 100 \mathrm{~g}$ plant material. Rutin (quercetin 3-O-rutinoside) and isoquercitrin (quercetin 3-O-glucoside) were identified in the ethanolic extract, but they were in too low concentration to be quantified. The three glycosides of quercetin detected only in A. distans subsp. alpina, could be used as a potential taxonomic marker in order to distinguish the subspecies. Caffeic acid and chlorogenic acid were also identified in the extract of A. distans subsp. alpina (Table 1). Considering the 19 standard compounds used in this study (Table 2), some other peaks were not identified.

Thus, the comparative study showed large differences, especially quantitative, between the two taxa of Achillea distans. The richest subspecies in aglycones of flavonoids (luteolin, apigenin, quercetin) was $A$. distans subsp. distans, but the flavonoid glycosides were not found.

\subsection{Polyphenolic and Flavonoid Contents of the Extracts}

Flavonoids and phenolic acids make up one of the most pervasive groups of plant phenolics. The plants and herbs consumed by humans may contain various amounts of different phenolic acid and flavonoid components. The effect of dietary phenolics is currently of great interest due to their antioxidant and possible anticarcinogenic activities. Phenolic acids and flavonoids also function as reducing agents, free radical scavengers, and quenchers of singlet oxygen. In addition, flavonoids and phenolic acids components play important roles in the control of cancer and other human diseases. Due to their importance in plants and human health, it would be useful to know the concentration of the polyphenolic compounds and biological activities that could indicate their potentials as therapeutic agents, and also for predicting and controlling the quality of medicinal herbs [27].

The total polyphenolic content (TPC) values summarized for Achillea extracts in Table 3 were quantified based on the linear equation obtained from gallic acid standard calibration curve. Thus, TPC values were expressed as gallic acid equivalent (mg GAE/g sample). The calculation of total flavonoid content of plant extracts was carried out using the standard curve of rutin and presented as rutin equivalents (mg RE/g sample). The highest amount of the total polyphenols was determined in the 
extract of $A$. distans subsp. alpina flowers $\left(174.75 \pm 1.47 \mathrm{mg} \cdot \mathrm{g}^{-1}\right)$ followed by $A$. distans subsp. distans extract $\left(101.61 \pm 1.24 \mathrm{mg} \cdot \mathrm{g}^{-1}\right)$. Concerning the content of flavonoids, contrary, the extract of A. distans subsp. distans $\left(37.26 \pm 0.71 \mathrm{mg} \cdot \mathrm{g}^{-1}\right)$ was richer in flavonoids, than the extract of $A$. distans subsp. alpina $\left(33.18 \pm 0.60 \mathrm{mg} \cdot \mathrm{g}^{-1}\right)$.

Table 3. The content of total polyphenols and flavonoids in A. distans extracts.

\begin{tabular}{ccc}
\hline Samples & TPC (mg GAE/g plant material) & Flavonoids (mg RE/g plant material) \\
\hline A. distans subsp. distans & $101.61 \pm 1.24$ & $37.26 \pm 0.71$ \\
A. distans subsp. alpina & $174.75 \pm 1.47$ & $33.18 \pm 0.60$ \\
\hline
\end{tabular}

Each value is the mean $\pm \mathrm{SD}$ of three independent measurements. GAE: Gallic acid equivalents; RE: rutin equivalents.

\subsection{Antioxidant Activity}

The antioxidant capacity of the ethanolic extracts of flowers heads of $A$. distans subsp. distans and A. distans subsp. alpina was determined by several methods: DPPH bleaching assay, the Trolox equivalent antioxidant capacity (TEAC), Electron Paramagnetic Resonance (EPR) method, and the hemoglobin ascorbate peroxidase activity inhibition (HAPX) assay (Table 4).

Table 4. Antioxidant capacity parameters obtained using several methods for studied Achillea samples.

\begin{tabular}{ccccc}
\hline Samples & $\begin{array}{c}\text { DPPH } \\
(\% \text { decolorization) }\end{array}$ & $\begin{array}{c}\mathbf{I C}_{\mathbf{5 0}} \\
\left(\boldsymbol{\mu g} \cdot \mathbf{m L}^{-\mathbf{1}}\right)\end{array}$ & $\begin{array}{c}\text { TEAC }(\boldsymbol{\mu m o l ~ T r o l o x} / \\
\mathbf{m g}_{\text {plant material) }}\end{array}$ & HAPX (\%) \\
\hline A. distans subsp. distans & $52.73 \pm 0.77$ & $204.85 \pm 2.93$ & $42.14 \pm 0.48$ & $4.91 \pm 1.24$ \\
A. distans subsp. alpina & $93 \pm 1.47$ & $83.80 \pm 1.20$ & $46.72 \pm 0.35$ & $10.27 \pm 1.81$ \\
Quercetin & - & $5.60 \pm 0.35$ & - & - \\
BHT & - & $16 \pm 0.54$ & - & - \\
\hline
\end{tabular}

Each value is the mean $\pm \mathrm{SD}$ of three independent measurements.

The antioxidant activity of the ethanol extracts was further assessed by the DPPH radical bleaching method. The DPPH scavenging ability of the subspecies alpina was 1.76 times larger than that of the subspecies distans at the same concentration $(218.75 \mu \mathrm{g}$ plant product $/ \mathrm{mL}$ extract) (Table 4). The highest radical scavenging activity was showed by the extract of $A$. distans subsp. alpina with $\mathrm{IC}_{50}=83.80 \pm 1.20 \mu \mathrm{g} \cdot \mathrm{mL}^{-1}$, followed by the extract of $A$. distans subsp. distans $\left(\mathrm{IC}_{50}=204.85 \pm 2.93\right)$. This is in good agreement with the TPC values listed in Table 3. Compared to the reference compounds, quercetin $\left(\mathrm{IC}_{50}=5.60 \pm 0.35 \mu \mathrm{g} \cdot \mathrm{mL}^{-1}\right)$ and BHT $\left(\mathrm{IC}_{50}=16 \pm 0.54 \mu \mathrm{g} \cdot \mathrm{mL}^{-1}\right)$, the ethanol extracts of $A$. distans showed lower antioxidant capacity. According to this method, A. distans subsp. alpina extract exhibited a moderate antioxidant capacity $\left(50 \mu \mathrm{g} / \mathrm{mL}<\mathrm{IC}_{50} \leq 100 \mu \mathrm{g} \cdot \mathrm{mL}^{-1}\right)$, and the ethanol extract of $A$. distans subsp. distans has no relevant antioxidant activity $\left(\mathrm{IC}_{50}>200 \mu \mathrm{g} \cdot \mathrm{mL}^{-1}\right)$. In the TEAC assay, the stable radical is dissolved in an aqueous solution, thus expecting a different mechanism of interaction between antioxidants molecule and the radical since TEAC assesses the more hydrophilic components while DPPH describes all components. This can be observed by the final TEAC values (Table 4), even though the antioxidant power is significantly higher in $A$. distans subsp. alpina extract, the difference in absolute value is not so great as in the case of DPPH method. 
Thus, it can be speculated that the $A$. distans subsp. distans extract contain antioxidant compounds which better act in aqueous solution than in organic solvent (ethanol). In the HAPX assay one measures, in a physiological relevant manner, the capability of the extract components to quench the $\mathrm{HbFe}^{\mathrm{IV}}$ resulted by hydrogen peroxide-induced damage upon $\mathrm{HbFe}^{\mathrm{III}}$. The results further indicate that by this assay too, $A$. distans subsp. alpina extract is double more antioxidant than $A$. distans subsp. distans extract. Figure 3 illustrates the results of an antioxidant assay using electron paramagnetic spectroscopy (EPR). This assay also indicate that $A$. distans subsp. alpina extract has a comparable activity to that of gallic acid and $A$. distans subsp. distans extract has three times less activity than gallic acid. A. distans subsp. alpina extract is much more antioxidant than A. distans subsp. distans extract.

Figure 3. TEMPO consumption $(1.4 \mathrm{mM})$ by $A$. distans subsp. distans (ADD) and A. distans subsp. alpina (ADA). The experimental data were fitted with exponential decay function according to the equation $\mathrm{I}(\mathrm{t})=\mathrm{I}_{0}+\mathrm{I}_{1} \mathrm{e}^{-\mathrm{kt}}$, and the kinetic constants are $\mathrm{k}_{\mathrm{ADA}}=0.126 ; \mathrm{k}_{\mathrm{ADD}}=0.04$. Gallic acid was used as control, $\mathrm{k}_{\text {gallic acid }}=0.131$, at a concentration of $6 \mathrm{mg} / \mathrm{mL}$.

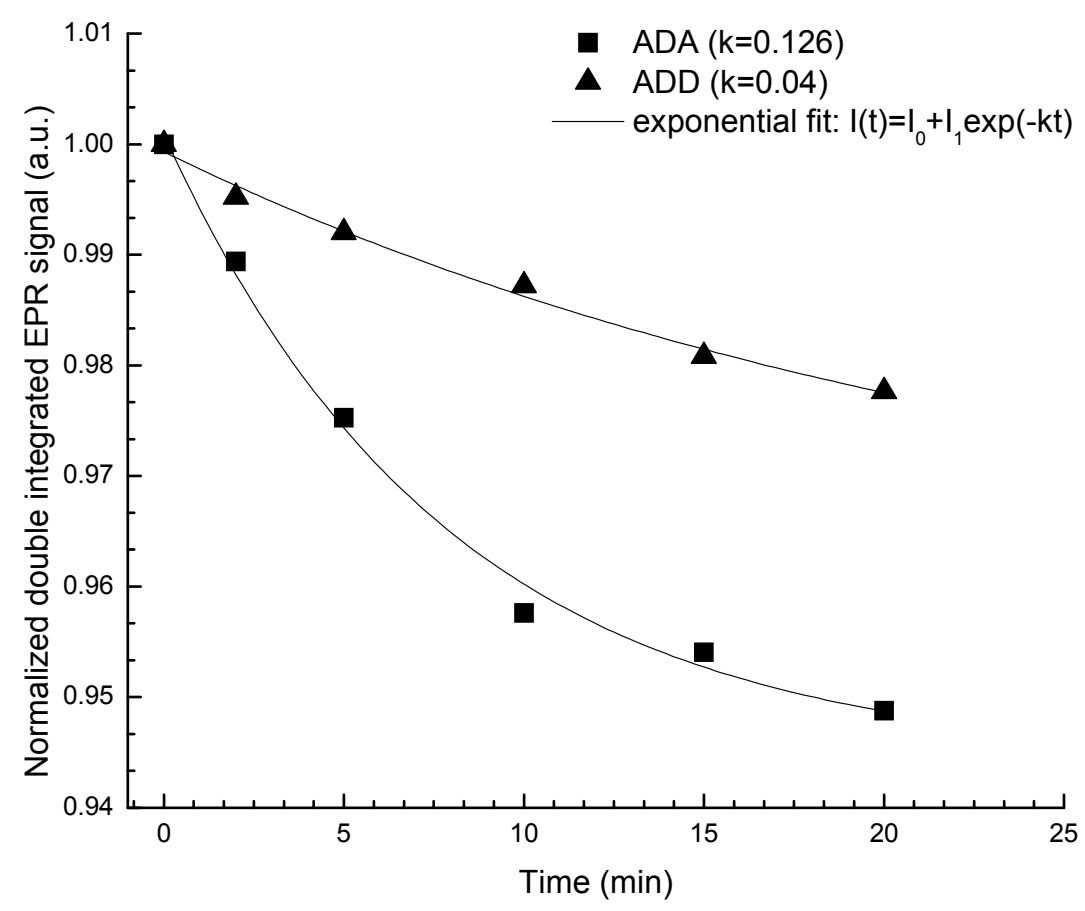

\subsection{Antibacterial Activity}

The antibacterial activity of the ethanol extracts of $A$. distans is shown in the Table 4 . The antibacterial activity is ranked from no activity (-: inhibition diameter $<10 \mathrm{~mm}$ ), low (+: inhibition diameter between 10 and $15 \mathrm{~mm}$ ), moderate (++: inhibition diameter between 15 and $20 \mathrm{~mm}$ ) and high activity (+++: diameter inhibition $\geq 20 \mathrm{~mm}$ ). The extracts were investigated for their in vitro antimicrobial properties using a disk-diffusion method against $S$. aureus, L. monocytogenes, E. coli, S. typhymurium [28,29] (Table 5). 
Table 5. Antibacterial activity (inhibition zone expressed in $\mathrm{mm}$ ) ${ }^{\mathrm{a}}$ of two investigated extracts of $A$. distans.

\begin{tabular}{ccccc}
\hline \multirow{2}{*}{ Samples } & \multicolumn{4}{c}{ Inhibition zone in diameter (mm) } \\
\cline { 2 - 5 } & $\begin{array}{c}\text { Staphylococcus } \\
\text { aureus }\end{array}$ & $\begin{array}{c}\text { Listeria } \\
\text { monocytogenes }\end{array}$ & $\begin{array}{c}\text { Escherichia } \\
\text { coli }\end{array}$ & $\begin{array}{c}\text { Salmonella } \\
\text { typhymurium }\end{array}$ \\
\hline A. distans subsp. distans & $13.0 \pm 0.05$ & $17.0 \pm 0.1$ & $10.0 \pm 0.05$ & $7.0 \pm 0.00$ \\
A. distans subsp. alpina & $12.0 \pm 0.07$ & $12.0 \pm 0.00$ & $8.0 \pm 0.05$ & $6.0 \pm 0.02$ \\
Gentamicin & $19 \pm 0.05$ & $18 \pm 0.1$ & $22 \pm 0.00$ & $18 \pm 0.05$ \\
\hline
\end{tabular}

Notes: ${ }^{\text {a }}$ The values represent the average of three determinations \pm standard deviations. Gentamicin $(10 \mu \mathrm{g} / \mathrm{disk})$ was used as a positive control.

The extract of $A$. distans subsp. distans showed a moderate activity towards $L$. monocytogenes (inhibition diameter between 15 and $20 \mathrm{~mm}$ ), a low antibacterial effect towards $S$. aureus and E. coli (inhibition diameter between 10 and $15 \mathrm{~mm}$ ), and inactive against S. typhymurium (inhibition diameter $<10 \mathrm{~mm}$ ). The extract of $A$. distans subsp. alpina showed a low antibacterial activity towards $S$. aureus, L. monocytogenes, and it did not show antibacterial activity against the tested gram-negative bacterial strains.

\section{Experimental}

\subsection{Plant Material and Extraction Procedure}

The flowers of Achillea distans Waldst. et Kit. ex Willd. subsp. distans (voucher No. 953) and the flowers of Achillea distans Waldst. et Kit. subsp. alpina (Rochel) Soo (voucher No.954) were collected in August 2011 (Rodna Mountains, in the north of the Eastern Carpathians, near Iezer Lake, at 1700-1750 m altitude, Romania) in the blossom period. Voucher specimens were deposited in the Herbarium of the Department of Pharmaceutical Botany of the Faculty of Pharmacy, Cluj-Napoca, Romania. The plant material (flowers) was reduced to a proper degree of fineness. $2.0 \mathrm{~g}$ of the material was extracted with $20 \mathrm{~mL}$ of $70 \%$ ethanol (Merck, Darmstadt, Germany), for $30 \mathrm{~min}$ on a water bath, at $60{ }^{\circ} \mathrm{C}$. The samples were then cooled down and centrifuged at 4,500 rpm for $15 \mathrm{~min}$, and the supernatant was recovered $[24,26]$.

\subsection{Chemicals}

Chlorogenic acid, $p$-coumaric acid, caffeic acid, rutin, apigenin, quercetin, isoquercitrin, quercitrin, hyperoside, kaempferol, myricetol, fisetin from Sigma (St. Louis, MO, USA), ferulic acid, sinapic acid, gentisic acid, gallic acid, patuletin, luteolin from Roth (Karlsruhe, Germany), cichoric acid, caftaric acid from Dalton (Toronto, ON, Canada). HPLC grade methanol, analytical grade orthophosphoric acid, hydrochloric acid and Folin-Ciocalteu reagent were purchased from Merck, hydrogen peroxide, ABTS (2,2'-azinobis-3-ethylbenzotiazoline-6-sulphonic acid) were from Sigma (St. Louis, MO, USA); aluminum chloride, sodium acetate, sodium carbonate, ethanol (Merck), DPPH (2,2-diphenyl-1-picrylhydrazyl) and BHT (butylated hydroxytoluene) were obtained from Alfa-Aesar (Karlruhe, Germany). Bovine hemoglobin was purified following the general protocol of Antonini and Brunori [30]. The met forms of hemoglobin were prepared by ferricyanide treatment as previously 
described [31]. All microorganism products were distributed by MicroBioLogics ${ }^{\circledR}$ : Staphylococcus aureus ATCC 49444 (Gram+), Listeria monocytogenes ATCC 13076 (Gram+), Escherichia coli ATCC 25922 (Gram-), and Salmonella typhymurium ATCC 14028 (Gram-).

\subsection{HPLC/MS Analysis}

\subsubsection{Apparatus and Chromatographic Conditions}

The experiment was carried out using an Agilent Technologies 1100 HPLC Series system (Agilent, Santa Clara, CA, USA) equipped with G1322A degasser, G13311A binary gradient pump, column thermostat, G1313A autosampler and G1316A UV detector. The HPLC system was coupled with an Agilent 1100 mass spectrometer (LC/MSD Ion Trap VL). For the separation, a reverse-phase analytical column was employed (Zorbax SB-C18 $100 \times 3.0 \mathrm{~mm}$ i.d., $3.5 \mu \mathrm{m}$ particle); the work temperature was $48{ }^{\circ} \mathrm{C}$. The detection of the compounds was performed on both UV and MS mode. The UV detector was set at $330 \mathrm{~nm}$ until $17.5 \mathrm{~min}$, then at $370 \mathrm{~nm}$. The MS system operated using an electrospray ion source in negative mode. The chromatographic data were processed using ChemStation and DataAnalysis software from Agilent. The mobile phase was a binary gradient: methanol and acetic acid $0.1 \%(\mathrm{v} / \mathrm{v})$. The elution started with a linear gradient, beginning with $5 \%$ methanol and ending at $42 \%$ methanol, for $35 \mathrm{~min}$; then $42 \%$ methanol for the next 3 minutes [24-26]. The flow rate was $1 \mathrm{~mL} \cdot \mathrm{min}^{-1}$ and the injection volume was $5 \mu \mathrm{L}$.

The MS signal was used only for qualitative analysis based on specific mass spectra of each polyphenol. The MS spectra obtained from a standard solution of polyphenols were integrated in a mass spectra library. Later, the MS traces/spectra of the analysed samples were compared to spectra from library, which allows positive identification of compounds, based on spectral mach. The UV trace was used for quantification of identified compounds from MS detection. Using the chromatographic conditions described above, the polyphenols eluted in less than 40 min (Table 2). Four polyphenols cannot be quantified in current chromatographic conditions due overlapping (caftaric acid with gentisic acid and caffeic acid with chlorogenic acid). However, all four compounds can be selectively identified in MS detection (qualitative analysis) based on differences between their molecular mass and MS spectra. For all compounds, the limit of quantification was $0.5 \mu \mathrm{g} / \mathrm{mL}$, and the limit of detection was $0.1 \mu \mathrm{g} \cdot \mathrm{mL}^{-1}$. The detection limits were calculated as minimal concentration producing a reproductive peak with a signal-to-noise ratio greater than three. Quantitative determinations were performed using an external standard method. Calibration curves in the $0.5-50 \mu \mathrm{g} \cdot \mathrm{mL}^{-1}$ range with good linearity $\left(\mathrm{R}^{2}>0.999\right)$ for a five point plot were used to determine the concentration of polyphenols in plant samples [24-26].

\subsubsection{Identification and Quantification of Polyphenols}

The detection and quantification of polyphenols was performed in UV assisted by mass spectrometry detection. Due to peak overlapping, four polyphenol-carboxylic acids (caftaric, gentisic, caffeic, chlorogenic) were determined only based on MS spectra, whereas for the rest of the compounds the linearity of the calibration curves was very good $\left(\mathrm{R}^{2}>0.998\right)$, with detection limits in the range of 18 to $92 \mathrm{ng} \cdot \mathrm{mL}^{-1}$. The detection limits were calculated as the minimal concentration 
yielding a reproducible peak with a signal-to-noise ratio greater than three. Quantitative determinations were performed using an external standard method; retention times were determined with a standard deviation ranging from 0.04 to $0.19 \mathrm{~min}$ (Table 2). For all compounds, the accuracy was between $94.13 \%$ and $105.3 \%$. Accuracy was checked by spiking samples with a solution containing each polyphenol in a $10 \mu \mathrm{g} \cdot \mathrm{mL}^{-1}$ concentration. In all analyzed samples the compounds were identified by comparison of their retention times and recorded electrospray mass spectra with those of standards in the same chromatographic conditions.

\subsection{Determination of Total Polyphenols and Flavonoids Content}

The total phenolic content (TPC) of the extracts was determined by the Folin-Ciocalteau method with some modifications [32-35]. Each ethanolic extract $(2 \mathrm{~mL})$ diluted 25 times was mixed with Folin-Ciocalteu reagent $(1.0 \mathrm{~mL})$ and distilled water $(10.0 \mathrm{~mL})$ and diluted to $25.0 \mathrm{~mL}$ with a $290 \mathrm{~g} / \mathrm{L}$ solution of sodium carbonate. The samples were incubated in the dark for $30 \mathrm{~min}$. The absorbance was measured at $760 \mathrm{~nm}$. Gallic acid was used as standard for the calibration curve and was plotted at 0.02 , $0.04,0.06,0.08$, and $0.10 \mathrm{mg} \cdot \mathrm{mL}^{-1}$, prepared in methanol-water $(50: 50, \mathrm{v} / \mathrm{v})$. TPC values were determined using an equation obtained from the calibration curve of gallic acid graph $\left(\mathrm{R}^{2}=0.9990\right)$.

The spectrophotometric aluminum chloride method was used for flavonoids determination. Each extract $(5 \mathrm{~mL})$ was mixed with sodium acetate $\left(5.0 \mathrm{~mL}, 100 \mathrm{~g} \cdot \mathrm{L}^{-1}\right)$, aluminum chloride $\left(3.0 \mathrm{~mL}, 25 \mathrm{~g} \cdot \mathrm{L}^{-1}\right.$, and filled up to $25 \mathrm{~mL}$ by methanol in a calibrated flask. The absorbance was measured at $430 \mathrm{~nm}$ [36]. Total flavonoids content values was determined using an equation obtained from calibration curve of the rutin graph $\left(\mathrm{R}^{2}=0.9996\right)$.

\subsection{Antioxidant Activity Test}

\subsubsection{DPPH• Radical Scavenging Assay}

The free radical scavenging activity of the ethanolic extracts of the two subspecies of $A$. distans was measured in terms of hydrogen donating or radical scavenging ability using the stable DPPH radical method. A DPPH solution $\left(0.1 \mathrm{~g} \cdot \mathrm{L}^{-1}\right)$ in methanol was prepared and this solution $(4.0 \mathrm{~mL})$ was added to of extract solution (or standard) in methanol at different concentrations $\left(\left(4.0 \mathrm{~mL}, 10-50 \mu \mathrm{g} \cdot \mathrm{mL}^{-1}\right)\right.$. After 30 min of incubation at $40{ }^{\circ} \mathrm{C}$ in a thermostatic bath, the decrease in the absorbance $(n=3)$ was measured at $517 \mathrm{~nm}$. The percent DPPH scavenging ability was calculated as: DPPH scavenging ability $=\left(\mathrm{A}_{\text {control }}-\mathrm{A}_{\text {sample }} / \mathrm{A}_{\text {control }}\right) \times 100$, where $\mathrm{Abs}_{\text {control }}$ is the absorbance of DPPH radical + methanol (containing all reagents except the sample) and $\mathrm{Abs}_{\text {sample }}$ is the absorbance of DPPH radical + sample extract. Afterwards, a curve of \% DPPH scavenging capacity versus concentration was plotted and $\mathrm{IC}_{50}$ values were calculated. $\mathrm{IC}_{50}$ denotes the concentration of sample required to scavenge $50 \%$ of DPPH free radicals $[16,21,34,37-40]$. The positive controls were those using the standard solution quercetin and butylated hydroxytoluene $(\mathrm{BHT}) . \mathrm{IC}_{50}$ value is related with the antioxidant capacity. So, $\mathrm{IC}_{50} \leq 50 \mu \mathrm{g} / \mathrm{mL}$ value means a high antioxidant capacity; $50 \mu \mathrm{g} / \mathrm{mL}<\mathrm{IC}_{50} \leq 100 \mu \mathrm{g} \cdot \mathrm{mL}^{-1}$ value means a moderate antioxidant capacity and $\mathrm{IC}_{50}>200 \mu \mathrm{g} \cdot \mathrm{mL}^{-1}$ value means no relevant antioxidant capacity [39]. 


\subsubsection{Trolox Equivalent Antioxidant Capacity (TEAC) Assay}

In a quartz cuvette, to phosphate buffer saline (PBS, $955 \mu \mathrm{L}$ ) the following were added: Achillea extracts $\left(20 \mu \mathrm{L}\right.$, diluted 100 times), and $\operatorname{ABTS}^{+\bullet}(25 \mu \mathrm{L}$, from $74 \mathrm{mM}$ stock solution). The experiments were done in duplicates, with a relative standard deviation of less than $6 \%$. The Achillea extract in the assay mixture was $8.24 \mathrm{mg} \cdot \mathrm{L}^{-1}$. The content of the generated $\mathrm{ABTS}^{\bullet+}$ radical was measured at $734 \mathrm{~nm}$ after $600 \mathrm{~s}$ reaction time and was converted in Trolox equivalents by the use of a calibration curve $\left(\mathrm{R}^{2}=0.9987\right)$ constructed with $0,2,4,6,8,10 \mathrm{mg} \cdot \mathrm{L}^{-1}$ Trolox standards $[41,42]$.

\subsubsection{Hemoglobin/Ascorbate Peroxidase Activity Inhibition (HAPX) Assay}

In a quartz cuvette sodium acetate buffer $(956 \mu \mathrm{L}, 50 \mathrm{mM}, \mathrm{pH} 5.5)$, was mixed with ascorbic acid $(7 \mu \mathrm{L}, 50 \mathrm{mM})$, hydrogen peroxide $(20 \mu \mathrm{L}, 50 \mathrm{mM})$ and 10-times diluted extracts of $A$. distans ssp. distans and $A$. distans ssp. alpina $\left(10 \mu \mathrm{L}\right.$, final concentration of $\left.82.4 \mathrm{mg} \mathrm{L}^{-1}\right)$. After $12-15 \mathrm{~s}$, met-hemoglobin (met-Hb) from a $1.4 \mathrm{mM}$ stock solution $(7 \mu \mathrm{L})$ was added to the reaction mixture and the $290 \mathrm{~nm}$ absorbance was further monitored. A measurable significant inhibition of the ascorbic acid consumption was observed compared to the reference (run in four different experiments) in which the extract was replaced by an equal amount of extraction solvent $[31,43]$. The slope of each sample was calculated at the tested concentration and also without the tried sample (blank). The inhibition of the ascorbic acid consumption was determined as follows: HAPX $=100-[$ (slope of the sample/slope of the blank) $\times 100$ ]. All the spectroscopic measurements were performed using a Jasco V-530 UV-Vis spectrophotometer (Jasco International Co., Ltd., Tokyo, Japan).

\subsubsection{EPR (Electron Paramagnetic Resonance) Spectroscopy Method}

The EPR spectra were measured using an EMX Micro spectrometer (Bruker BioSpin GmbH, Rheinstetten, Germany). EPR instrument conditions were as follows: microwave frequency $9.43 \mathrm{GHz}$, microwave power $15.89 \mathrm{~mW}$, modulation frequency $100 \mathrm{kHz}$, modulation amplitude $3 \mathrm{G}$, sweep rate $10 \mathrm{G} / \mathrm{s}$; time constant $10.24 \mathrm{~ms}$, average of three sweeps for each spectrum, room temperature. For the 2,2,6,6-tetramethylpiperidin-1-yl)oxyl (TEMPO) radical scavenging by the extract monitored by EPR, $3.43 \mathrm{mM}$ TEMPO $(20 \mu \mathrm{L})$ was quickly mixed with extract $(30 \mu \mathrm{L})$ and transferred with a syringe to an an EPR micro tube. The EPR signal is registered at defined time interval and the double integrals are calculated. The kinetic profile obtained is fitted with a first order exponential decay function and the kinetic constant is considered an antioxidant parameter [44]. Gallic acid was used as control.

\subsection{Antibacterial Activity Test}

The ethanolic extracts of $A$. distans were tested for antimicrobial activity against two Gram-positive bacterial strains: Staphylococcus aureus (ATCC 49444), Listeria monocytogenes (ATCC 13076), and against two Gram-negative bacterial strains: Escherichia coli (ATCC 25922), Salmonella typhymurium (ATCC 14028) by a previously described disc diffusion method, in Petri dishes [28,29]. Each microorganism was suspended in Mueller Hinton (MH) broth and diluted approximately to 10E6 colony forming unit (cfu)/mL. They were "flood-inoculated" onto the surface of $\mathrm{MH}$ agar and $\mathrm{MH}$ Dextroxe Agar (MDA) and then dried. Six-millimeter diameter wells were cut from the agar using a 
sterile cork-borer, and $60 \mu \mathrm{L}$ of each extract were delivered into the wells. The plates were incubated at $37{ }^{\circ} \mathrm{C}$ and the diameters of the growth inhibition zones were measured after $24 \mathrm{~h}$. Gentamicin (10 $\mu \mathrm{g} / \mathrm{well})$ was used as positive control. The controls were performed with only sterile broth and with only overnight culture and $10 \mu \mathrm{L}$ of $70 \%$ ethanol $[28,29]$. All tests were performed in triplicate, and clear halos greater than $10 \mathrm{~mm}$ were considered as positive results.

\subsection{Statistical Analysis}

All the samples were analyzed in triplicate, except those for EPR method wich were analyzed in duplicate; the average and the relative SD were calculated using the Excel software package.

\section{Conclusions}

We have determined the phenolic profile, the antioxidant and antibacterial activities for two indigenous subspecies of Achillea distans and we have completed the literature data with new information concerning the polyphenolic compounds and their bioactivity. The simultaneous determination of a wide range of polyphenolic compounds was performed using a rapid, highly accurate and sensitive HPLC method assisted by mass spectrometry detection. The antioxidant activity evaluated using the DPPH (2,2-diphenyl-1-picrylhydrazyl) bleaching method, Trolox equivalent antioxidant capacity assay (TEAC), hemoglobin ascorbate peroxidase activity inhibition (HAPX) assay, and an Electron Paramagnetic Resonance (EPR) spectroscopy method, indicate that $A$. distans subsp. alpina extract is more antioxidant than A. distans subsp. distans extract, related with the polyphenolic total content.

The comparative study showed significant differences, both qualitative and especially quantitative, between the two taxa of Achillea distans. This study suggests that the flowers of $A$. distans subsp. alpina and $A$. distans subsp. distans from Romania may be considered a source of important polyphenols with bioactive properties, a source that could be pharmaceutically exploited.

\section{Acknowledgements}

Financial support provided by "Iuliu Hatieganu" University of Medicine and Pharmacy of Cluj-Napoca, Romania (research grant: 27020/43/15.11.2011) and Romanian Ministry for Education and Research (grant PCCE 140/2008) is gratefully acknowledged.

\section{Conflict of Interest}

The authors declare no conflict of interest.

\section{References}

1. Ciocârlan, V. Illustrated Flora of Romania. Pteridophyta et Spermatophyta; Ceres Publishing House: Bucharest, Romania, 2009; pp. 794-799.

2. Tutin, T.G.; Heywood, V.H.; Burges, N.A.; Valentine, D.H.; Walters, S.M.; Webb, D.A. Flora Europaea; Cambridge University Press: Cambridge, UK, 1976; Volume 4, pp. 162-163. 
3. Tamas, M.; Popovici, M.; Oniga, I.; Oprean, I.; Coldea, G. Infraspecific chemical taxa of Achillea distans Waldst. et Kit. from the Rodnei Mountains (Eastern Carpathians) -Romania. Planta Med. 2009, 75, 932.

4. Popovici, M.; Vlase, L.; Oniga, I.; Tamas, M. HPLC analyses on polyphenolic compounds from Achillea species. Farmacia 2007, 3, 353-357.

5. Popovici, M.; Pârvu, A.E.; Oniga, I.; Toiu, A.; Tamas, M.; Benedec, D. Effects of two Achillea species tinctures on experimental acute inflammation. Farmacia 2008, 1, 15-23.

6. Todorova, M.N.; Mikhova, B.; Trendafilova, A.; Vitkova, A.; Duddeck, H. Terpenoids from Achillea distans Waldst. \& Kit. ex Willed. Biochem. Syst. Ecol. 2007, 12, 852-858.

7. Konakchiev, A.; Todorova, M.; Mikhova, B.; Vitkova, A.; Najdenski, H. Composition and antimicrobial activity of Achillea distans essential oil. Nat. Prod. Commun. 2011, 6, 905-906.

8. Lazarevic, J.; Radulović, N.; Zlatković, B.; Palić, R. Composition of Achillea distans Willd. subsp. distans root essential oil. Nat. Prod. Res. 2010, 8, 718-731.

9. Dai, J.; Mumper, J.R. Plant phenolics: Extraction, analysis and their antioxidant an anticancer properties. Molecules 2010, 15, 7313-7352.

10. Kundaković, T.; Stanojković, T.; Juranić, Z.; Kovacević, N. Cytotoxic and antioxidant activity of Achillea alexandri-regis. Pharmazie 2005, 4, 319-320.

11. Özer, H.; Sökmen, M.; Bariş, Ö.; Şahin, F.; Özkan, H.; Güllüce, M.; Kiliç, H.; Özbek, T. Biological activities of the essential oil and methanol extract of Achillea biebersteinii Afan (Asteraceae). Turk. J. Biol. 2006, 30, 65-73.

12. Vitalini, S.; Grande, S.; Visioli, F.; Agradi, E.; Fico, G.; Tome, F. Antioxidant activity of wild plants collected in Valsesia, an alpine region of Northern Italy. Phytother. Res. 2006, 7, 576-580.

13. Nickavar, B.; Kamalinejad, M.; Haj-Yahya, M.; Shafaghi, B. Comparison of the free radical scavenging activity of six Iranian Achillea species. Pharm. Biol. 2006, 44, 208-212.

14. Ardestani, A.; Yazdanparast, R. Antioxidant and free radical scavenging potential of Achillea santolina extracts. Food Chem. 2007, 104, 21-29.

15. Koleckar, V.; Opletal, L.; Brojerova, E.; Rehakova, Z.; Cervenka, F.; Kubikova, K.; Kuca, K.; Jun, D.; Polasek, M.; Kunes, J.; et al. Evaluation of natural antioxidants of Leuzea carthamoides as a result of a screening study of 88 plant extracts from the European Asteraceae and Cichoriaceae. J. Enzyme Inhib. Med. Chem. 2008, 2, 218-224.

16. Eghdami, A.; Sadeghi, F. Determination of total phenolic and flavonoids contents in methanolic and aqueous extract of Achillea millefolium. Org. Chem. J. 2010, 2, 81-84.

17. Vitalini, S.; Beretta, G.; Iriti, M.; Orsenigo, S.; Basilico, N.; Dall'Acqua, S.; Iorizzi, M.; Fico, G. Phenolic compounds from Achillea millefolium L. and their bioactivity. Acta Biochim. Pol. 2011, 2, 203-209.

18. Wojdyło, A.; Oszmianski, J.; Czemerys, R. Antioxidant activity and phenolic compounds in 32 selected herbs. Food Chem. 2007, 105, 940-949.

19. Saeidnia, S.; Gohari, A.; Mokhber-Dezfuli, N.; Kiuchi, F. A review on phytochemistry and medicinal properties of the genus Achillea. Daru. 2011, 3, 173-186.

20. Tuberoso, C.I.; Montoro, P.; Piacente, S.; Corona, G.; Deiana, M.; Dessì, M.A.; Pizza, C.; Cabras, P. Flavonoid characterization and antioxidant activity of hydroalcoholic extracts from Achillea ligustica All. J. Pharm. Biomed. Anal. 2009, 3, 440-448. 
21. Bozin, B.; Mimica-Dukic, N.; Bogavac, M.; Suvajdzic, L.; Simin, N.; Samojlik, I.; Couladis, M. Chemical composition, antioxidant and antibacterial properties of Achillea collina Becker ex Heimerl s.l. and A.pannonica Scheele essential oils. Molecules 2008, 13, 2058-2068.

22. Giorgi, A.; Madeo, M.; Speranza, G.; Cocucci, M. Influence of environmental factors on composition of phenolic antioxidants of Achillea collina Becker ex Rchb. Nat. Prod. Res. 2010, $16,1546-1559$.

23. Turkoglu, I.; Turkoglu, S.; Celik, S.; Kahyaoglu, M. Antioxidant and antimicrobial activities of Turkish endemic Achillea species. Afr. J. Microbiol. Res. 2010, 4, 2034-2042.

24. Meda, R.N.T.; Vlase, L.; Lamien-Meda, A.; Lamien, C.E.; Muntean, D.; Tiperciuc, B.; Oniga, I.; Nacoulma, O.G. Identification and quantification of phenolic compounds from Balanites aegyptiaca (L) Del (Balanitaceae) galls and leaves by HPLC-MS. Nat. Prod. Res. 2011, 25, 93-99.

25. Vlase, L.; Marcel Parvu, M.; Parvu, E.A.; Toiu, A. Chemical Constituents of Three Allium Species from Romania. Molecules 2013, 18, 114-127.

26. Benedec, D.; Vlase, L.; Hanganu, D.; Oniga, I. Antioxidant potential and polyphenolic content of Romanian Ocimum basilicum. Dig. J. Nanomater. Bios. 2012, 7, 1263-1270.

27. Ghasemzadeh, A.; Ghasemzadeh, N. Flavonoids and phenolic acids: Role and biochemical activity in plants and human. J. Med. Plants Res. 2011, 31, 6697-6703.

28. Reeves, D.S.; White, L.O. Principles of Methods of Assaying Antibiotics in Pharmaceutical Microbiology, 3rd ed.; Blackwel: Oxford, UK, 1983; pp. 140-162.

29. Zbakh, H.; Chiheb H.; Bouziane, H.; Motilva Sánchez, V.; Riadi, H. Antibacterial activity of benthic marine algae extracts from the Mediterranean coast of Morocco. JMBFS 2012, 1, 219-228.

30. Antonini, E.; Brunori, M. Hemoglobin and Myoglobin in Their Reaction with Ligands; North-Holland Pub. Co.: Amsterdam, The Netherlands, 1971.

31. Mot, A.C.; Damian, G.; Sarbu, C.; Silaghi-Dumitrescu, R. Redox reactivity in propolis: Direct detection of free radicals in basic medium and interaction with hemoglobin. Redox Rep. 2009, 14, 267-274.

32. Council of Europe. European Pharmacopoeia, 5th ed.; Council of Europe: Strasbourg Cedex, France, 2005; Volume 1, p. 221.

33. Tamokou, J.D.D.; Chouna, J.R.; Fischer-Fodor, E.; Chereches, G.; Barbos, O.; Damian, G.; Benedec, D.; Duma, M.; Nkeng Efouet, P.A.; Wabo, H.K.; et al. Anticancer and antimicrobial activities of some antioxidant-rich cameroonian medicinal plants. PLoS One 2013, 2, e55880.

34. Singleton, V.L.; Orthofer, R.; Lamuela-Raventos, R.M. Analysis of total phenols and other oxidation substrates and antioxidants by means of Folin-Ciocalteu reagent. Method. Enzymol. 1999, 299, 152-178.

35. Slinkard, K.; Singleton, V.L. Total phenol analyses: Automation and Comparison with Manual Methods. Am. J. Enol. Vitic. 1977, 28, 49-55.

36. Romanian Pharmacopoeia Commission National Medicines Agency. Romanian Pharmacopoeia, Xth ed.; Medical Publishing House Bucharest: Bucharest, Romania, 1993; p.335.

37. Adiguzel, A.; Ozer, H.; Sokmen, M.; Gulluce, M.; Sokmen, A.; Kilic, H.; Sahin, F.; Baris, O. Antimicrobial and antioxidant activity of the essential oil and methanol extract of Nepeta cataria. Pol. J. Microbiol. 2009, 58, 69-76. 
38. Nimmi, O.S.; George, P. Evaluation of the antioxidant potential of a newly developed polyherbal formulation for antiobesity. Int. J. Pharm. Pharm. Sci. 2012, 4, 505-510.

39. Simirgiotis, M.J. Antioxidant Capacity and HPLC-DAD-MS Profiling of Chilean Peumo (Cryptocarya alba) Fruits and Comparison with German Peumo (Crataegus monogyna) from Southern Chile. Molecules 2013, 18, 2061-2080.

40. Zadra, M.; Piana, M.; Faccim de Brum, T.; Boligon, A.A.; Borba de Freitas, R.; Machado, M.M.; Stefanello, S.T.; Soares, F.A.A.; Athayde, M.L. antioxidant activity and phytochemical composition of the leaves of Solanum guaraniticum A. St.-Hil. Molecules 2012, 17, 12560-12574.

41. Obón, J.M.; Castellar, M.R.; Cascales, J.A.; Fernández-López, J.A. Assessment of the TEAC method for determining the antioxidant capacity of synthetic red food colorants. Food Res. Int. 2005, 38, 843-845.

42. Prior, R.L.; Wu, X.; Schaich K. Standardized methods for the determination of antioxidant capacity and phenolics in foods and dietary supplements. J. Agric. Food Chem. 2005, 53, 4290-4302.

43. Cooper, C.E.; Silaghi-Dumitrescu, R.; Rukengwa, M.; Alayash, A.I.; Buehler, P.W. Peroxidase activity of hemoglobin towards ascorbate and urate: A synergistic protective strategy against toxicity of hemoglobin-based oxygen carriers (HBOC). Biochim. Biophys. Acta 2008, 1784, 1415-1420.

44. Espinoza, M.; Olea-Azar, C.; Speisky, H.; Rodríguez, J. Determination of reactions between free radicals and selected Chilean wines and transition metals by ESR and UV-Vis technique. Spectrochim. Acta A Mol. Biomol. Spectrosc. 2009, 71, 1638-1643.

Sample Availability: Samples are available from the authors.

(C) 2013 by the authors; licensee MDPI, Basel, Switzerland. This article is an open access article distributed under the terms and conditions of the Creative Commons Attribution license (http://creativecommons.org/licenses/by/3.0/). 